\title{
Availability and Utilization of Primary Healthcare Centre in Thanjavur District, Tamilnadu
}

\author{
Dr. R. Sudharsan ${ }^{1 *}$, Dr. V. Saravanabavan ${ }^{2}$ \\ ${ }^{1}$ Functional Area Expert, ABM Enviro Tech Pvt Ltd, Salem, Madurai, Tamil Nadu, India \\ ${ }^{2}$ Assistant Professor, Department of Geography, Madurai Kamaraj University, Madurai, Tamil Nadu, India
}

\begin{abstract}
Health is a common theme in most cultures. Among the definitions still used, probably the oldest is that health is not the absence of disease. Contemporary developments in social sciences reveal that health is not only a biomedical phenomenon, but one which is influenced by social, psychological, cultural, economic and political factors of the people concerned. Thanjavur District lies on the east of Tamil Nadu. It is situated between $9^{0}$ 50 'and $11^{\circ} 25^{\prime}$ of the northern latitude and between $78^{\circ} 45^{\prime}$ and $79^{\circ} 25^{\prime}$ of the eastern longitude. It extends to an area of 3411 sq. kms. Our sample in Thanjavur, we found more people depending upon the public health facilities than on the private health facilities. Almost $74 \%$ people went to public health facilities and only $26 \%$ went to the private health facilities. The health status of various blocks of the district in relation to other blocks with reference to socio-economic living, environment, family structure and health care utilization but also emphasized the intra regional variation that exists among different bocks in the health status of the population.

The present study is based on the major aims and objectives as follows.

$>$ To study the socio-economic characterization of patients' rural healthcare performance.

$>$ To study the characteristics of diseases and the implementation of healthcare facilities, availability and utilization of the primary health services in the rural areas of Thanjavur block wise details.

However, in the selection of the blocks few points were considered such as the distance of these villages from the urban area and access to the facilities of the rural area. This plays an important role in the improvement of healthcare centre in Thanjavur district. Different geographic regions of Thanjavur district with reference to the PHC patient, their family, family type, socio economic characteristics, Accessibility and healthcare facilities and environmental setting, etc., were analyzed with the help of descriptive statistical analysis tools.
\end{abstract}

Keywords : Patients Performance -Travel Behavioural pattern- Proximity

\section{INTRODUCTION}

Health is a common theme in most cultures. Among the definitions still used, probably the oldest is that health is not the absence of disease. Contemporary developments in social sciences reveal that health is not only a biomedical phenomenon, but one which is influenced by social, psychological, cultural, economic and political factors of the people concerned.
Rural areas also suffer from the lack of basic amenities such as electricity, appropriate drainage and sewage, etc., which further contribute to poor hygiene and increased susceptibility to diseases. Many healthcare systems are started in the rural area for the very poor people who are sick. Most of the people are farmers and they are not healthy because of poverty and also they are not getting healthy food and nutrition. By this health care system the 
government serves the free nutrition and free medical checkups for diseases like diabetes, BP, delivery cases etc. Over the last few decades, there has been a tremendous improvement in the quality of healthcare services in India. The improvement in the healthcare indicators is a direct result of the improved penetration of healthcare services in terms of the increase in the number of government and private hospitals in India. There is a noted increase in the number of allopathic doctors with recognized medical qualifications, who have registered with state medical councils.

Hence, the National Rural Health Mission was initiated in 2005 in order to decide the issues of accessibility and affordability of healthcare to the population below the poverty line and the lower and middle classes, in rural India.

\section{Health care}

Health is the act of taking preventative or necessary medical procedures to improve a person's well being. This may be done with the administering of medicine, surgery or other alterations in person's life style. These services are typically offered through a health care system made up of hospitals and physicians.

\section{Rural Healthcare in Thanjavur District}

In the infrastructure of healthcare facilities of Thanjavur, the manpower position is not very satisfactory. We find all the levels of the health institutions lack the availability of the required manpower. While the sub centers and PHCs mainly have insufficient paramedical staff, the Community Healthcare Centres also have a crunch of specialist doctors. Availability of better physical infrastructure in public health facilities can become more or less ineffective in providing quality health service due to inadequate human resources. In our sample in Thanjavur, we found more people depending upon the public health facilities than on the private health facilities. Almost $74 \%$ people went to public health facilities and only $26 \%$ went to the private health facilities.

\section{Selection of Study area}

Medical geography studies the geographical environment of human society and its influence on health of man. In this direction the present study helps to understand how the socio economic status of healthcare performance of patients is governed by behavior medical factors. Thanjavur District lies on the east of Tamil Nadu. It is situated between $9^{0}$ 50 'and $11^{\circ} 25^{\prime}$ of the northern latitude and between $78^{\circ} 45^{\prime}$ and $79^{\circ} 25^{\prime}$ of the eastern longitude.(Fig.1) It extends to an area of 3411 sq. kms. Geographically Thanjavur is situated in the midway along the course of river Vadavar and Vennar at an altitude of 57 meters above mean sea level. The climate is tropical and the district falls under the category of medium and high rainfall region with average rainfall around $1020 \mathrm{~mm}$. Majority of the rain is received through North East Monsoon (October to early December). 


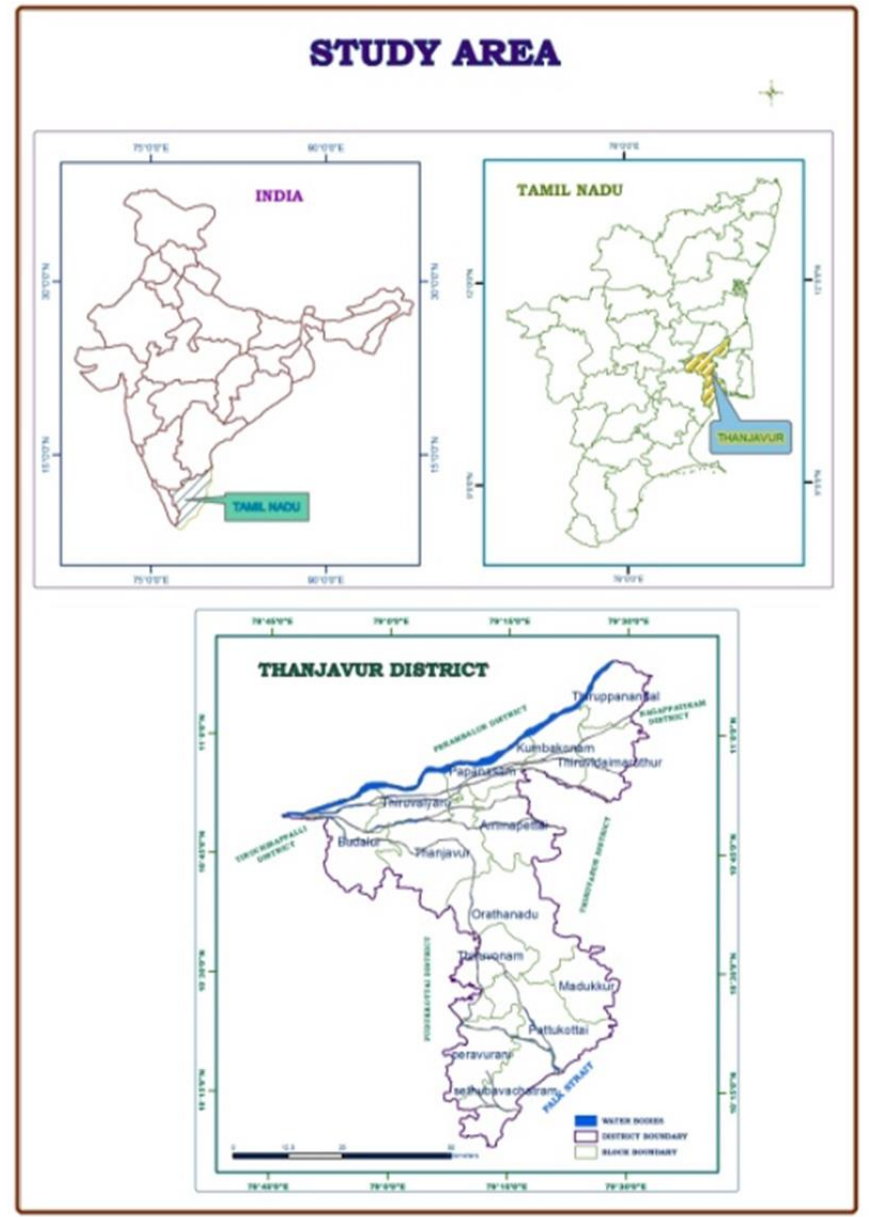

Figure 1

\section{Aim and Objectives}

The main objectives of the study to analyze the socioeconomic status and healthcare performance of the patients in Thanjavur district. An analysis of the socio-economic characterization of patients rural healthcare performance and study the characteristics of diseases and the implementation of healthcare facilities. To understand the health and nutritional status of different geographic regions of Thanjavur district with reference to the PHC patient, family type, socio economic characteristics, health facilities, etc.

\section{METHODS AND MATERIAL}

\subsection{Data Collection and Methodology}

To fulfill the above objectives, the information was collected from both primary and secondary sources.
The data area collected through a survey of patients who have utilized the PHCs seeking health care for various types of illnesses. There were totally 560 samples who were interviewed by direct questionnaire method. The Primary data suitable coded were converted in the form of univariate, bivariate and multivariate tables to represent the characteristics in the form of charts and graphs.

\subsection{Population Characteristics}

Thanjavur district had a total population of 2405890 persons in 2011 provisional census. Spread over an area 3411sq.km. There were about 1182416 men according to 2011 census and 1096638 men in 2001 census marking an increase of 85778 men over the previous census. During 2001 there were about 1119500 women, which increased to 1223474 in 2011 census. The study area has an average population density of about 650 persons per sq.km in 2001 census. It has increased to 705 persons per sq.km in 2011. In 2011 men constitute 49.15 percent of the total population and women 50.85 percent of the total population. The sex ratio was 980 during 2001 and 966 during 2011. (Table.1)

Literate accounted for 1476256 persons (66.61 percent) in 2001 and increased to persons 74.41 percent in 2011. There were about 814354 males 74.26 percent classed as literate in 2001 and 79.86 percent in 2011 census. There were about 661902 females 59.12 percent classed as literates in 2001. This increased to persons 69.21 percent in 2011 census.

Table 1 Thanjavur District Population Characteristics - 2001 and 2011

\begin{tabular}{|l|c|c|c|c|}
\hline Characteristics & 2001 & $\%$ & 2011 & $\%$ \\
\hline $\begin{array}{l}\text { Total } \\
\text { Population }\end{array}$ & 2216138 & - & 2405890 & - \\
\hline $\begin{array}{l}\text { Male } \\
\text { Population }\end{array}$ & 1096638 & 49.48 & 1182416 & 49.15 \\
\hline Female & 1119500 & 50.52 & 1223474 & 50.85 \\
\hline
\end{tabular}




\begin{tabular}{|l|c|c|c|c|}
\hline Population & & & & \\
\hline $\begin{array}{l}\text { Rural } \\
\text { Population }\end{array}$ & 1467577 & 66.22 & 1554531 & 64.61 \\
\hline $\begin{array}{l}\text { Urban } \\
\text { Population }\end{array}$ & 748561 & 33.78 & 851359 & 35.39 \\
\hline $\begin{array}{l}\text { Density per } \\
\text { sq.km }\end{array}$ & & 649.70 & & 705.33 \\
\hline Sex Ratio & & 979.58 & & 966.44 \\
\hline Literates & 1476256 & 66.61 & 1790998 & 74.44 \\
\hline Male Literacy & 814354 & 74.26 & 944264 & 79.86 \\
\hline $\begin{array}{l}\text { Female } \\
\text { Literacy }\end{array}$ & 661902 & 59.12 & 846734 & 69.21 \\
\hline
\end{tabular}

Source: Census of Tamilnadu, 2001, 2011

\subsection{Healthcare Performance of the Patients}

Perception of People on Health Care Systems

- Transport Facilities on Health Care Systems

- Accessibility of Location of Healthcare Centre

\subsection{Perception of People on Health Care Systems}

\subsubsection{Rural Medical Services}

The medical service available in an area is also important for the study on Disease related matters. Among the respondents $93 \%$ of them were satisfied with medical service available in Thanjavur district and about $6 \%$ of (fig.2) they were not satisfied with the facilities available in the study area. (Table.2)

Table 2. Distribution of the Respondents of Rural Medical Services

\begin{tabular}{|c|c|c|}
\hline Satisfy & $\begin{array}{c}\text { No. of } \\
\text { Respondents }\end{array}$ & Percentage \\
\hline Yes & 524 & 93.57 \\
\hline No & 36 & 6.43 \\
\hline Total & 560 & 100 \\
\hline
\end{tabular}

Source: Compiled by the author.

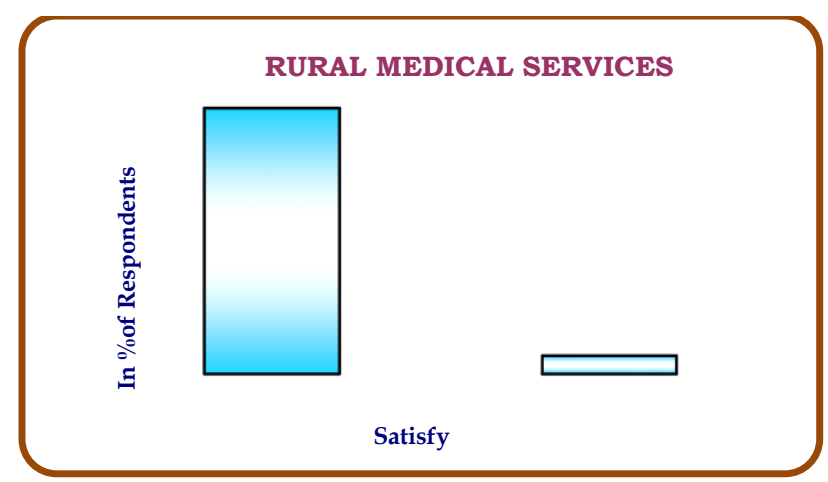

Fig.2

\subsubsection{Visit to Healthcare Centre}

The visit by the rural population to healthcare centre is analyzed in table 95 percent of the people in the rural area visited PHC's and those who visited government hospital is 3 percent. People visiting private health facility is only 0.54 percent. (Table.3) (Fig.3)

Table 3. Distribution of the Respondents of Visit of Healthcare Centre

\begin{tabular}{|l|c|c|}
\hline Health centre & $\begin{array}{c}\text { No. of } \\
\text { Respondents }\end{array}$ & Percentage \\
\hline G.H & 22 & 3.93 \\
\hline $\begin{array}{l}\text { Private } \\
\text { Hospital }\end{array}$ & 3 & 0.54 \\
\hline PHC & 535 & 95.54 \\
\hline Total & 560 & 100 \\
\hline
\end{tabular}

Source: Compiled by the author.

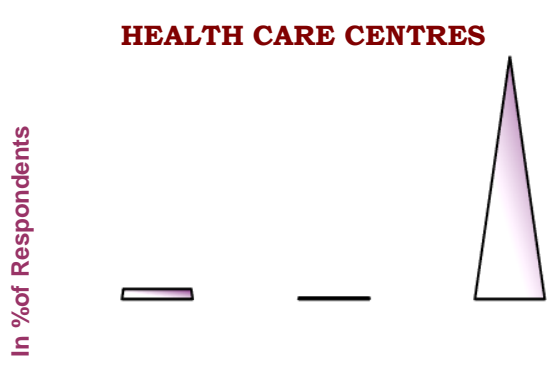

Healthcare centres

Fig.3 


\subsubsection{Cost of Treatment}

In the sample survey, about 15 percent of the respondents spend less than 100 Rupees for their treatment and 27 percent of the respondents spent Rs. 100 - 150 for the treatment. Likewise 16 percent (Fig.4) of the respondents spend Rs.150 - 300 and 3 percent of the people spend more than 300 rupees. 39 percent did not spend any money for treatment. (Table.4)

Table 4. Distribution of the Respondents of Cost of Treatment

\begin{tabular}{|l|c|c|}
\hline $\begin{array}{c}\text { Amount } \\
\text { (Rs.) }\end{array}$ & $\begin{array}{c}\text { No. of } \\
\text { Respondents }\end{array}$ & Percentage \\
\hline$<100$ & 85 & 15 \\
\hline $100-150$ & 151 & 27 \\
\hline $150-300$ & 88 & 16 \\
\hline$>300$ & 17 & 3 \\
\hline Not spend & 219 & 39 \\
\hline Total & 560 & 100 \\
\hline
\end{tabular}

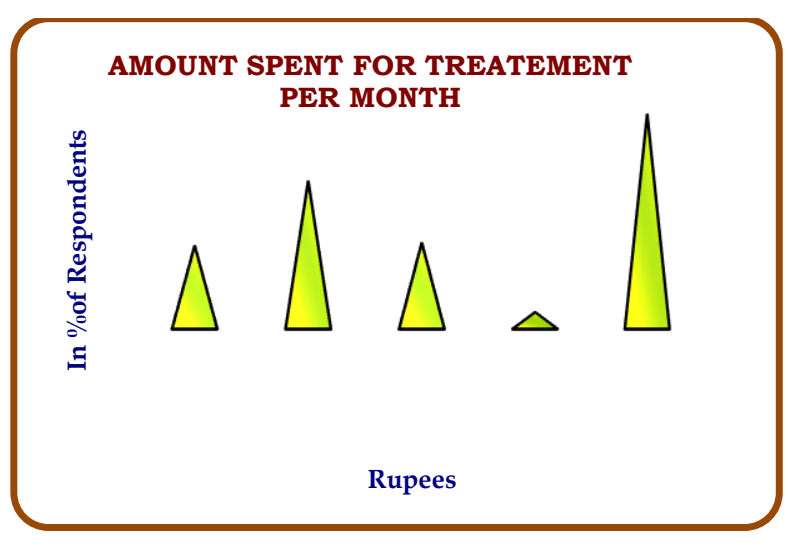

Fig. 4

\subsubsection{Treatment Preferred}

The type of treatment that people choose is analyzed in table. 11 About 91.96 percent of the respondents avail non medicine treatment and 6 percent of the respondents follow Siddha treatment. 0.18 percent of the respondents follow Homeopathic and Ayurvedha treatment 1.25 percent of the respondents follow Traditional treatment. (Fig.5) in all blocks the two main systems of treatment is Allopathy and Siddha. Once in a week Homeopathy and Ayurvedha system of treatments are given. In some PHC naturopathy is also practiced. (Table.5)

Table 5. Distribution of the Respondents on Treatment Preferred

\begin{tabular}{|l|c|c|}
\hline $\begin{array}{l}\text { Other } \\
\text { medicine }\end{array}$ & $\begin{array}{l}\text { No. of } \\
\text { Respondents }\end{array}$ & Percentage \\
\hline Siddha & 36 & 6.43 \\
\hline Ayurvedha & 1 & 0.18 \\
\hline Homeopathy & 1 & 0.18 \\
\hline Traditional & 7 & 1.25 \\
\hline No medicine & 515 & 91.96 \\
\hline Total & 560 & 100 \\
\hline
\end{tabular}

Source: Compiled by the author.

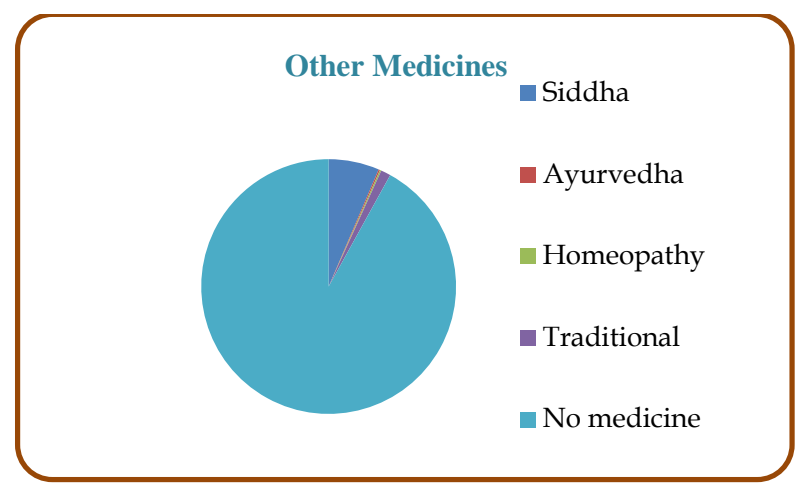

Fig.5

\subsubsection{Satisfaction of Medical Services}

The medical services available in an area and satisfaction of the services are analyzed in Table. 6 Among the respondents 50.54 percent of them are satisfied with medical service available in Thanjavur district in block wise PHCs and about 48 percent of them said that it is good and 0.36 percent of people are highly satisfied in the rural medical services and those not satisfied covered 0.89 percent.(Fig.6) 
Table 6. Distribution of the Respondents about Satisfaction of Medical Services

\begin{tabular}{|l|c|c|}
\hline \multicolumn{1}{|c|}{ Treatment } & $\begin{array}{c}\text { No. of } \\
\text { Respondents }\end{array}$ & Percentage \\
\hline Satisfied & 283 & 50.54 \\
\hline $\begin{array}{l}\text { Highly } \\
\text { satisfied }\end{array}$ & 2 & 0.36 \\
\hline Good & 270 & 48.21 \\
\hline Not satisfied & 5 & 0.89 \\
\hline Total & 560 & 100 \\
\hline
\end{tabular}

Source: Compiled by the author

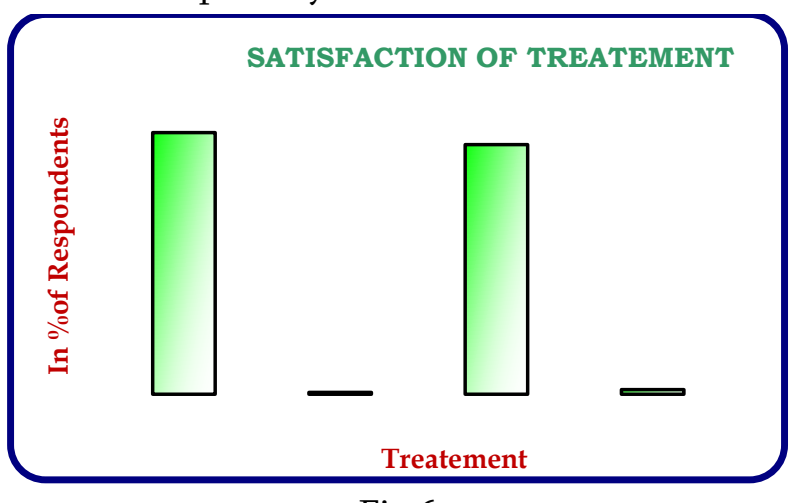

Fig. 6

\subsection{Transport Facilities on Health Care Systems}

\subsubsection{Transport Facilities}

Table.7 reveals that there are considerable differences in the movement pattern among the different groups. The transport facilities available to hospitals are a major determinant according to the analysis. About 95 percent of the respondents have Accessibility to Health care centres and 4 percent of them have no Accessibility because the locations of the PHCs are far away from their residence.(Fig.7)

Table 7. Distribution of Respondents Transport

$$
\text { Facilities }
$$

\begin{tabular}{|c|c|c|}
\hline Facility & $\begin{array}{c}\text { No. of } \\
\text { Respondents }\end{array}$ & Percentage \\
\hline Yes & 534 & 95.36 \\
\hline No & 26 & 4.64 \\
\hline Total & 560 & 100 \\
\hline
\end{tabular}

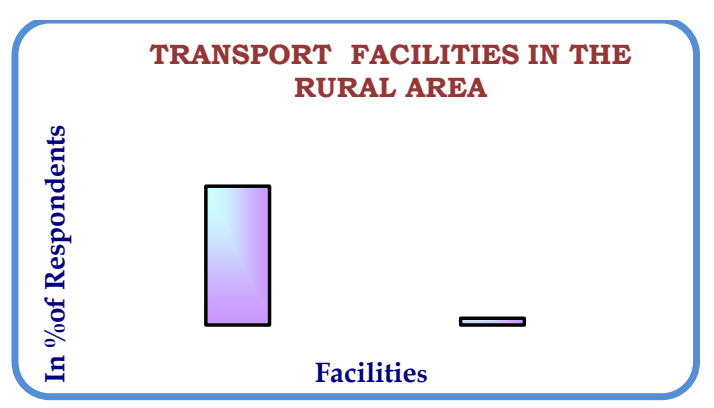

Source : Compiled by the author

Fig.7

\subsubsection{Availability of Public Transport}

In Table. 8 the availability of public transport to the respondents is analyzed. Most frequent service is available to 45 percent of the respondents and somewhat frequent service to 43 percent of the respondents in the rural areas. Infrequent transport services were available for 8 percent (Fig.8) of the respondents. No public transport was available for 2 percent of the respondents in Thanjavur district.

Table 8. Distribution of the Respondents on Availability of Public Transport

\begin{tabular}{|l|c|c|}
\hline \multicolumn{1}{|c|}{$\begin{array}{c}\text { Public } \\
\text { Transport }\end{array}$} & $\begin{array}{c}\text { No. of } \\
\text { Respondents }\end{array}$ & Percentage \\
\hline Most Frequent & 255 & 45.54 \\
\hline $\begin{array}{l}\text { Somewhat } \\
\text { Frequent }\end{array}$ & 242 & 43.21 \\
\hline Infrequent & 50 & 8.93 \\
\hline Not at all & 13 & 2.32 \\
\hline Total & 560 & 100 \\
\hline
\end{tabular}

Source: Compiled by the author 


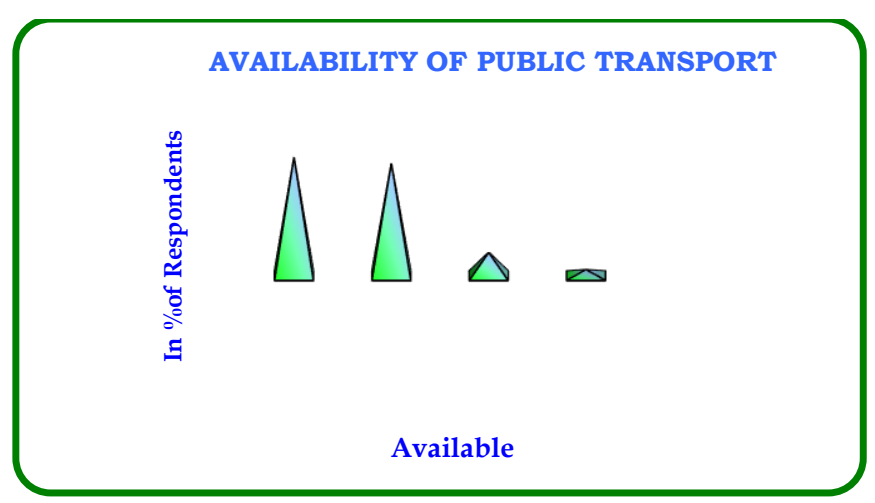

Fig.8

\subsubsection{Distance of Health Care Centre}

The distance between the residence and health centre is an important aspect in the planning of health care. About $41 \%$ of the respondents have less than $2 \mathrm{Km}$ of distance between $\mathrm{PHC}$ and their residence and $30 \%$ of the respondents are more than 2 - $4 \mathrm{Km}$ away from the Health centre. Likewise 14\% of the respondent are $4-6 \mathrm{Km}$ away from the Health centre and $13 \%$ of the respondents are $6 \mathrm{Km}$ away from the Primary Health Centre.

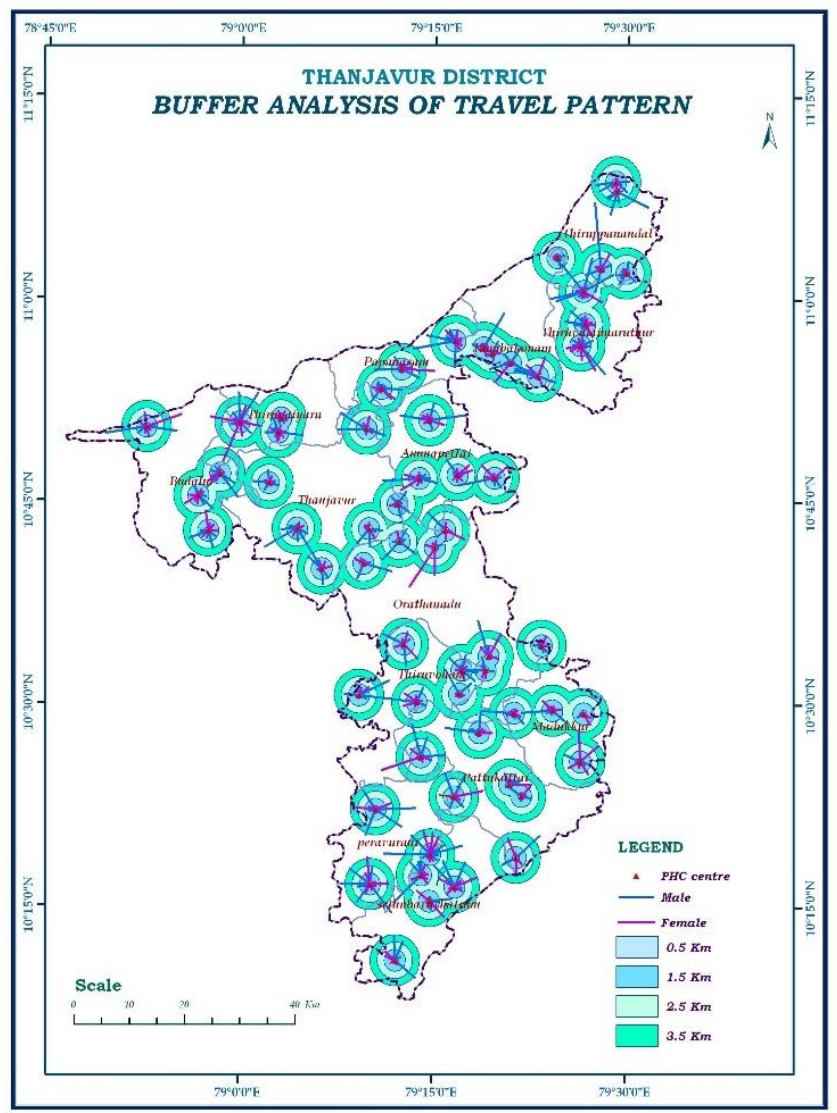

Fig.9
One way of defining accessibility to health centers is by knowing how far patients live from their nearest centre, (Fig.9) In this case the distance to provider is the main tool for measuring a centre's accessibility. Based on the planning standards of the Ministry of Municipal and Rural Affairs, every healthcare centre should cover a catchment area of maximum $3.5 \mathrm{~km}$ radius wide. Accordingly, patients residing within minimum $0.5 \mathrm{~km}$ distance of a Primary healthcare centre are entitled to receive services from this centre.(Fig.10)

Table 9. Distribution of the Respondents on Distance of Health Care Centre

\begin{tabular}{|l|c|c|}
\hline Distance & $\begin{array}{c}\text { No. of } \\
\text { Respondents }\end{array}$ & Percentage \\
\hline$<2$ & 235 & 41.96 \\
\hline $2-4$ & 168 & 30.00 \\
\hline $4-6$ & 83 & 14.82 \\
\hline$>6$ & 74 & 13.22 \\
\hline Total & 560 & 100 \\
\hline
\end{tabular}

Source: Compiled by the author.

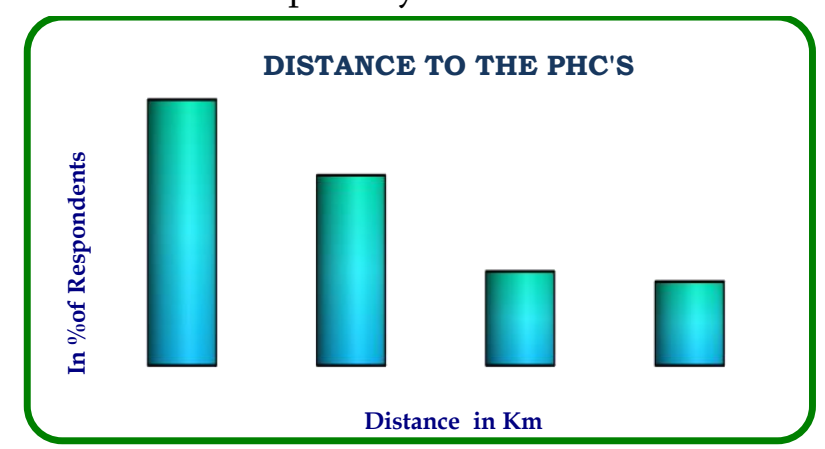

Fig. 10

\subsubsection{Mode of Transportation}

Table.10 clearly shows that the socio-economic status of the people by the mode of transportation. Public conveyance is preferred by about 37 percent of the respondents. 33 percent go on foot. 20 percent in the rural areas use bicycle. Two wheeler users are 6 percent.(Fig.11) 
Table 10. Distribution of the Respondents on Mode of Transportation

\begin{tabular}{|l|c|c|}
\hline \multicolumn{1}{|c|}{ Mode } & $\begin{array}{c}\text { No. of } \\
\text { Respondents }\end{array}$ & Percentage \\
\hline Walk & 187 & 33.39 \\
\hline Cycle & 113 & 20.18 \\
\hline Auto & 13 & 2.32 \\
\hline $\begin{array}{l}\text { Two } \\
\text { wheeler }\end{array}$ & 35 & 6.25 \\
\hline Bus & 212 & 37.86 \\
\hline Total & 560 & 100 \\
\hline
\end{tabular}

Source: Compiled by the author.

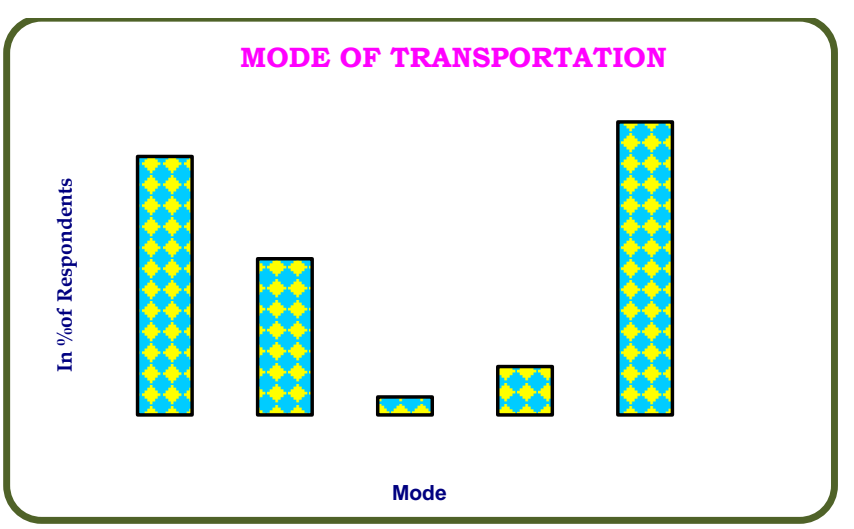

Fig. 11

\subsection{Accessibility of Location of Healthcare Centre}

The accessibility of health facility is analyzed in Table.11, 36 percent of the respondents have very high accessibility to the Health facility (Fig.12) and 59 percent of them have somewhat accessible and for the remaining 4 percent it is just accessible and it is not accessible for 1 percent of the respondents.(Fig.13)

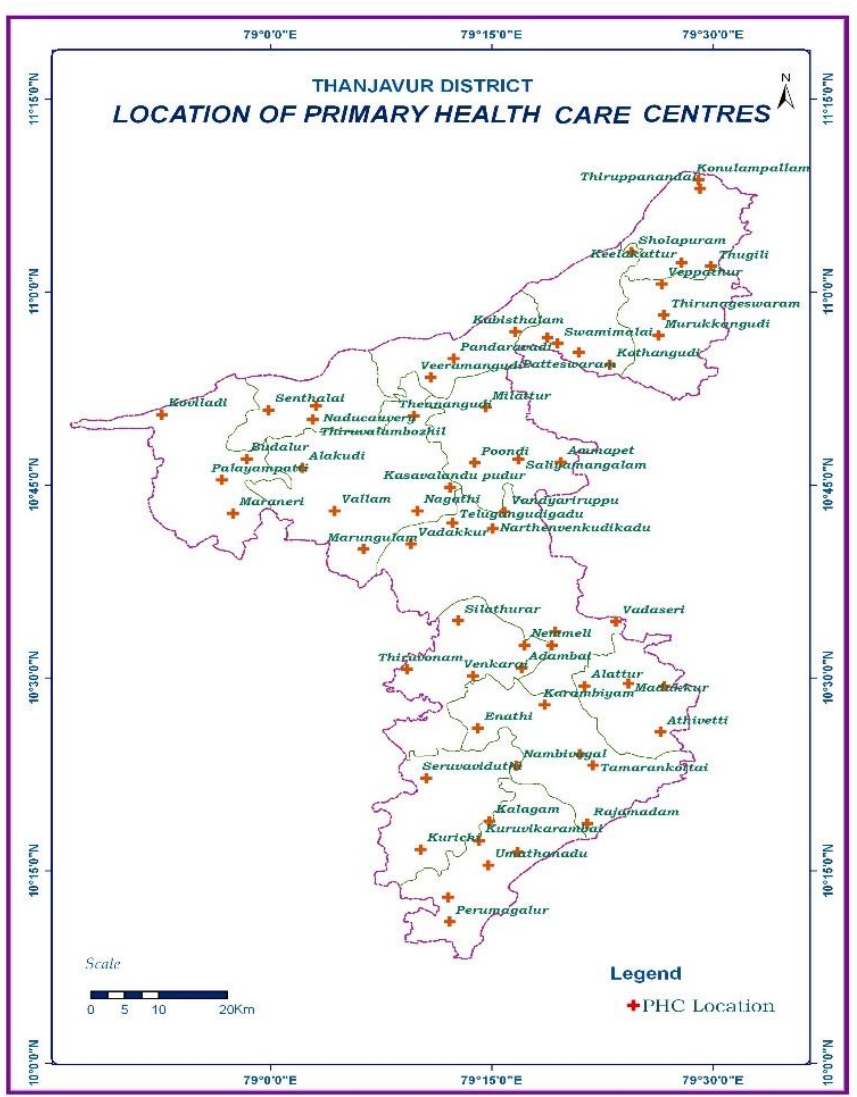

Fig. 12

Table.11 Distribution of the Respondents on Location of Healthcare Centre

\begin{tabular}{|l|c|c|}
\hline \multicolumn{1}{|c|}{ Location } & $\begin{array}{c}\text { No. of } \\
\text { Respondents }\end{array}$ & Percentage \\
\hline High Access & 205 & 36 \\
\hline $\begin{array}{l}\text { Somewhat } \\
\text { Access }\end{array}$ & 329 & 59 \\
\hline Accessible & 21 & 4 \\
\hline $\begin{array}{l}\text { Not } \\
\text { Accessible }\end{array}$ & 5 & 1 \\
\hline Total & 560 & 100 \\
\hline
\end{tabular}

Source: Compiled by the author. 


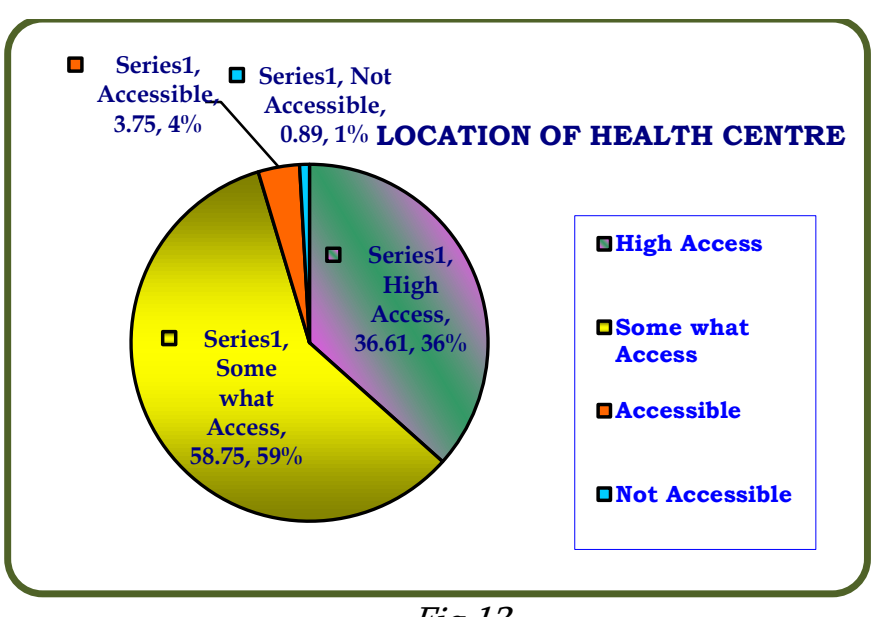

Fig.13

\section{Findings}

There are several limitations to our study that should be considered in its interpretation. First, we did not use theoretical iterative sampling, in which earlier interviews influence the subsequent selection of participants and we limited our sampling frame to physicians from a single state caring for adult patients only. Our findings identify a number of ways that physicians change care based on their patients' Socioeconomic status. These changes may contribute to measured socioeconomic disparities in health care; however, many changes are made to enhance patient outcomes given the constraints associated with low Socio-economic status. Explicit recognition of the role of socioeconomic factors in clinical decision making may be an important contribution in the development of quality standards to ensure highquality care and a physician workforce willing to care for susceptible populations.

\section{CONCLUSION}

The selection of these blocks were meaningfully done in order to get complete details of the surveyed population, their living environment, socio economic and socio-cultural and healthcare practices so as to conceptualize the findings with the help of health and disease pattern. Bring out the regional and intra regional variation that exists in the health status of the surveyed population were examined and interpreted. These graphs not only illustrate the health status of various blocks of the district in relation to other blocks with reference to socio economic living, environment, family structure and health care utilization but also emphasized the intra regional variation that exists among different bocks in the health status of the population.

\section{REFERENCES}

[1]. Bajpai, N., \& Dholakia, R. H. (2006). Scaling Up Primary Health Services in Rural Rajasthan. New York: The Earth Institute of Columbia University, CGSD Working Paper No. 32.

[2]. Bajpai, N., Dholakia, R. H., \& Sachs, J. D. (2005). Scaling Up Primary Healthcare Services in Rural India: Public Investment Requirements and Health Sector Reform in MP and UP. New York: The Earth Institute at Columbia Univeristy, CGSD Working Paper No.29.

[3]. Casalino LP, Alexander GC, Jin L, Konetzka RT. General internists' views on pay-for-performance and public reporting of quality scores: a national survey. Health Aff (Millwood). 2007;26(2):492499.

[4]. Ashlesha Datar, Arnab Mukherji. (2005), "Health infrastructure and Immunization coverage in rural India" Indian Journal of Medical, January 2007, pp.31-42.

[5]. Ronan Foley, Martin C. Charlton. A. Stewart Fotheringham, (2010) "GIS In Health and Social Care Planning".

[6]. Thomas (1976),"Socio-Spatial differentiation and the use of services in D.T.Herbert and R.J.Johnston (eds.) social areas in cities, $\mathrm{Vol} 2$, John Wiley and Sins, London,pp.17-63. 


\section{Cite this article as :}

Dr. R. Sudharsan, Dr. V. Saravanabavan, "Availability and Utilization of Primary Healthcare Centre in Thanjavur District, Tamilnadu", International Journal of Scientific Research in Science and Technology (IJSRST), Online ISSN : 2395-602X, Print ISSN : 2395-6011, Volume 6 Issue 4, pp. 288-297, JulyAugust 2019. Available at doi : https://doi.org/10.32628/IJSRST196451 Journal URL : http://ijsrst.com/IJSRST196451 